\title{
The Role of Regional Block and Sedation Accompanied Thoracoscopy on the Diagnosis and Treatment of Post-Trauma Patients Chest Tube Inserted
}

\author{
Travma Sonrası Göğüs Tüpü Uygulanan Hastalarda Rejyonel Blok ve Sedasyon Eşliğinde Torakoskopinin Tanı ve \\ Tedavideki Yeri \\ ${ }^{1}$ Mehmet Ali Eryazgan, ${ }^{2}$ Onur Karaca, ${ }^{3}$ Musa Zengin, ${ }^{4}$ Bulent Kocer
}

${ }^{1}$ Aksaray University, Faculty of Medicine, Department of Thoracic Surgery, Aksaray, Turkey

${ }^{2}$ Aksaray University, Faculty of Medicine, Department of Anesthesiology, Aksaray, Turkey

${ }^{3}$ University of Health Sciences, Ankara Atatürk Chest Diseases and Thoracic Surgery Training and Research Hospital, Department of Anesthesiology, Ankara, Turkey

${ }^{4}$ Ministry of Health, Ankara City Hospital, Department of Thoracic Surgery, Ankara, Turkey

Correspondence:

Musa ZENGIN- University of Health

Sciences, Ankara Atatürk Chest

Diseases And Thoracic Surgery

Training and Research Hospital,

Department of Anesthesiology,

Ankara, Turkey

e-mail: musazengin@gmail.com

\section{Abstract}

Traumatic hemothorax/pneumothorax; is a pathological condition seen in blunt and sharp thoracic traumas and can generally be treated by tube thoracostomy. While patients are being followed up with tube thoracotomy, analgesics support, and respiratory exercise support; emergency thoracotomy is usually not required. Early thoracoscopy is a method that has come to the fore in recent years. This thoracoscopy is known to have therapeutic and diagnostic benefits. In our study; the files of 40 patients who underwent tube thoracostomy after traumatic hemothorax/pneumothorax were reviewed retrospectively. Twenty of these patients, whose radiological and clinical improvement could not be achieved after tube thoracostomy, underwent thoracoscopy with sedo-analgesia on the first day after the procedure. The remaining 20 patients were followed up without any additional procedures. Patients' age, gender, trauma type, tube thoracostomy indication, presence of additional trauma, length of chest tube stay, length of hospital stay, $\mathrm{WBC}, \mathrm{RDW}, \% \mathrm{Neu}, \mathrm{pO} 2, \mathrm{pCO} 2, \mathrm{SO} 2$, presence of tube malposition, and complications were recorded from patient files. Demographic data of the two groups were similar. While tube withdrawal time was $4.7 \pm 1.5$ days in the thoracoscopy group, it was $6.9 \pm 1.9$ days in the control group. This difference was statistically significant $(p<0.001)$. The mean hospital stay was $7.1 \pm 2.0$ days in the first group, while it was $9.3 \pm 3.3$ days in the control group. This difference was statistically significant $(\mathrm{p}=0.014)$. In both groups, there was a $1(5 \%)$ patient who developed a need for thoracotomy. Thoracoscopy with sedo-analgesia in early period is a safe method for patients who have undergone tube thoracostomy due to trauma. This method reduces the duration of chest tube removal and hospital stay of patients. The need for thoracotomy after follow-up was similar in both groups.

Keywords: Hemothorax; pneumothorax; regional block; sedation; thoracic trauma; tube thoracostomy.

\section{Özet}

Travmatik hemo/pnömotoraks künt ve keskin toraks travmalarında görülen ve genellikle tüp torakostomi uygulanarak tedavi edilebilen patolojik durumdur. Hastalar tüp torakostomi, analjezik ve solunum egzersizi desteği ile izlenirken acil torakotomi genellikle gerekmez. Erken dönem torakoskopi uygulanması son yıllarda gündeme gelen bir yöntemdir ve bu torakoskopinin tedavi edici ve tanısal faydaları olduğu bilinmektedir. Çalışmamızda travmatik hemo/pnömotoraks sonrası tüp torakostomi uygulanmış 40 hastanın dosyası retrospektif olarak incelenmiştir. Tüp torakostomi uygulanması sonrası radyolojik ve klinik iyileşmesi sağlanamamış bu hasta grubunun 20'sine işlem sonrası birinci günde sedo-analjezi eşliğinde torakoskopi uygulanmış, 20'sine ise ek işlem uygulanmadan takibine devam edilmiştir. Hastaların yaşı, cinsiyeti, travma tipi, tüp torakostomi endikasyonu, ek travmasının varlığı, göğüs tüpü kalış süresi, hastanede yatış süresi, WBC, RDW, \%Neu, pO2, pCO2, SO2 değerleri, tüp malpozisyonu varlığı ve gelişen komplikasyonlar hasta dosyalarından kaydedilmiştir. Çalışmaya katılan iki grubun da demografik verileri benzerdi. Tüp çekilme süresi torakoskopi uygulanan grupta ortalama $4,7 \pm 1,5$ gün iken, kontrol grubunda ise ortalama $6,9 \pm 1.9$ gündü ve bu fark istatistiksel olarak anlamlıydı $(p<0,001)$. Torakoskopi uygulanan grubun hastanede yatış süresi ortalama 7,1 $\pm 2,0$ gün iken, kontrol grubunda ise ortalama 9,3 $\pm 3,3$ gündü ve bu fark istatistiksel olarak anlamlıydı $(\mathrm{p}=0,014)$. Her iki grupta da l'er (\%5) hastada torakotomi ihtiyacı geliști. Travma nedeni ile tüp torakostomi uygulanmış hastalara erken dönem sedoanaljezi ile torakoskopi uygulanması güvenli bir yöntemdir ve hastaların göğüs tüpünün çekilme süreleri ile hastanede kalış sürelerini azalttığı görülmektedir. Takip sonrası torakotomi gereksinimi ise iki grupta da benzer bulunmuștur.

Anahtar Kelimeler: Hemotoraks; pnömotoraks; rejyonel blok; sedasyon; toraks travması; tüp torakostomi 


\section{Introduction}

Thoracic injuries; affecting other systems due to the impact of vital organs and deterioration of oxygenation, are important causes of trauma-related deaths, especially between the ages of 20 and 40(1). In this age group, 20$25 \%$ of trauma-related deaths is caused by thoracic trauma (2). $70 \%$ of thoracic traumas are blunt and $30 \%$ are penetrating injuries. Chest traumas range from simple soft tissue injuries to life-threatening intrathoracic injuries.

In different studies, although thoracic pathologies in traumas vary; rib fractures are usually in the first place. Rib fracture occurs in $35-40 \%$ of patients with thoracic trauma. Treatment varies according to the age of the patient, the number of broken ribs, the accompanying pathologies and the condition of the underlying lung. Pneumothorax and hemothorax in the early period; may cause atelectasis and pneumonia in the late period. Its treatment is a good analgesia and a good control of bronchial secretions. In $5-15 \%$ of patients flail chest thorax trauma is seen (3).

The most common intrathoracic pathologies in thoracic traumas are pneumothorax, hemothorax and hemopneumothorax (4). The rate of thoracotomy in thoracic traumas is $10 \%$ in blunt traumas and $20-30 \%$ in penetrating traumas. Accepted thoracotomy indications: Presence of shock; presence of ongoing bleeding symptoms and signs (bleeding of $1000 \mathrm{ml}$ or more in tube thoracostomy, $200 \mathrm{ml} /$ hour bleeding in 2-4 hours, $100 \mathrm{ml} /$ hour bleeding in 6-8 hours, persistence of hypovolemic shock findings despite blood replacement); completely opaque appearance of one side hemithorax on chest radiograph; signs of hemopericardium or cardiac tamponade; increased or nondrainable hemothorax; tracheal, bronchial, or diffuse parenchyma laceration; and continued ( $>7$ days) massive air leak despite tube thoracostomy (5).

In traumatic hemothorax/pneumothorax the generally accepted first approach is thoracic tube application, and thoracotomy in case of hypoxia due to massive air leak or failure to maintain hemodynamic stability due to active bleeding (6). Although tube thoracostomy is a more easily applicable and inexpensive method, its effectiveness may be insufficient in some cases and therefore additional surgical interventions may be required. This can extend patient length of stay in the hospital for a longer period (7). Especially in cases with early removal of chest tubes, the incidence of retained hemothorax increases (8). This may force physicians to keep the chest tube in the intrapleural space for a longer period of time in cases treated with chest tube. Eddy et al. (9) emphasized that in emergency tube thoracostomy, the tube remained in the pleural space for a longer time due to inadequate drainage, and 5\% empyema developed as a result.

In the diagnosis and treatment of traumatic thoracic pathologies, studies related to videoassisted thoracoscopic surgery (VATS) have been carried out. VATS is recommended as a reliable method in the diagnosis and treatment of patients with hemodynamically stable and suspected hemothorax, hemopneumothorax, or diaphragmatic laceration or hernia $(10,11)$. In the treatment of traumatic hemothorax/pneumothorax, VATS seems to be superior in comparison to classical tube thoracostomy, in terms of providing direct diagnosis with diagnostic thoracoscopy, performing the treatment by providing the opportunity to intervene in the primary pathology, and preventing complications such as empyema, fibrothorax, and prolonged air leakage. These cases can be discharged early because the duration of chest tube stay and hospital stay are shorter (13).

Thoracoscopy with sedation and regional nerve blockade without the use of general anesthesia is a procedure that has started to evolve in recent years to avoid the complications of general anesthesia, and many surgical interventions, including lobectomy, can be performed with this method (14).

In our study, we aimed to analyze whether the application of thoracoscopy with early regional block and sedation in patients who underwent tube thoracostomy due to traumatic hemothorax/pneumothorax is superior compared to classical tube thoracostomy. 


\section{Material and Methods}

After approval from the local ethical committee (ID Number: E.Kurul-E-16-761, Date: 04.02.2016), between 07.01.2015 and 31.01.2016; medical form of patients who were in our hospital due to traumatic hemothorax/pneumothorax; underwent tube thoracostomy and did not improve radiologically or clinically on the first day after the procedure, were evaluated. Patients were over the age of 18 and did not need emergency thoracotomy or mechanical ventilator. Patients with following criteria were excluded: under the age of 18 ; who were connected to a mechanical ventilator; who needed emergency thoracotomy; who had undergone tube thoracostomy due to chronic reasons; or who recovered radiologically and clinically on the first day after tube thoracostomy.

In the study, there were 20 patients who were followed up with classical methods after tube thoracostomy and 20 patients who underwent thoracoscopy on the first day after tube thoracostomy. All patients were informed about the procedure and consent was obtained. Age, gender, trauma type, tube thoracostomy indication and presence of additional traumas were recorded. Drain removal time, hospital stay, complication development status, need for thoracotomy, white blood cell (WBC) on the 3rd day after the procedure, percentage of neutrophils (\%NEU), erythrocyte distribution with (RDW), partial oxygen pressure (pO2), partial pressure of carbon dioxide (pCO2) and oxygen saturation value ( $\mathrm{SO} 2$ ) were examined in both groups. Thoracoscopic findings were also recorded in the thoracoscopy group.

Hemogram and routine biochemistry tests were performed; bleeding-coagulation times were measured, blood gas values were followed, and echocardiography was performed for all patients followed-up by tube thoracostomy. Posteroanterior (PA) chest radiographs were taken for indication purposes before tube application, immediately after application and 1 day later for control purposes. Daily control and followed-up was continued with PA chest radiographs and routine blood tests.

A thoracic epidural block catheter was inserted between the T5-T6 vertebrae by the anesthesia team to the patients who will undergo thoracoscopy.

For premedication purposes; IV $50 \mathrm{mcg}$ fentanyl and $1 \mathrm{mg}$ midazolam were administered and additionally, $13 \mathrm{ml}$ of bupivacaine and $25 \mathrm{mcg}$ of fentanyl were administered through the epidural catheter. Before the procedure, $5 \mathrm{cc}$ bupivacaine with unilateral stellate ganglion blockade was also applied to the side where the procedure would be performed on these patients. Thus, the cough reflex that may develop due to contact with the lung parenchyma during exploration was temporarily blocked. Thoracoscopy procedure was performed with epidural block and sedation without intubating the patient. No new incisions were made in the patients and only the existing tube thoracostomy incision was used as a port.

After the appropriate lateral decubitus position was placed, a $15 \mathrm{~mm}$ trocar was inserted. Exploration of the thoracic cavity and lung parenchyma was achieved with a 2.5 $\mathrm{mm}$ or $5 \mathrm{~mm}$ optical camera through this incision. When intrathoracic pathologies such as hematoma, active bleeding, and adhesions were detected and it was necessary to intervene, the incision was expanded by $1 \mathrm{~cm}$ and the procedure was continued. During the procedure, the patient's vital signs, saturation value, and pain status were closely monitored. After the procedure, the patient underwent tube thoracostomy through the same incision. In order to prevent tube malposition; 3-4 new holes were made on the chest tube with the help of scissors, and the thoracoscope was inserted into the tube through one of these holes. Using the thoracoscope as a guide, the chest tube was placed in the appropriate position and the procedure was terminated. After the procedure, the patients were followed up with breathing exercises, appropriate analgesics and medication throughout the hospital stay. 
After tube thoracostomy, the group, which was followed-up with the classical method, was observed with daily PA chest radiographs and daily blood tests. During their hospitalization, these patients were followed up with breathing exercises, appropriate analgesics and medication.

\section{Statistical analyses}

The data of both groups in our study were analyzed with SPSS Windows 18 version. The distribution of variables was checked with the Kolmogorov Smirnov test. Mean, standard deviation and frequency values were used in the descriptive statistics of the data. Student T-test was used in the analysis of numerical nonparametric data. Pearson Chi-square test and Fisher's Chi-square test were used in the analysis of qualitative data. A $p$ value of $<0.05$ was considered statistically significant.

\section{Results}

The first group consists of patients who underwent thoracoscopy. The mean age of patients in first group was $38.7 \pm 12.3$ years, and the mean age of the control group, the second group, was $47.2 \pm 16.4$ years. There was no statistically significant difference between the groups in terms of age ( $p: 0.075$ ). In the first group; there were 18 (90.0\%) male and $2(10 \%)$ female. In the control group, there were $17(85.0 \%)$ male and $3(15.0 \%)$ female. There was no significant difference between the groups in terms of gender $(p>$ $0.05)$.

$9(22.5 \%)$ of the patients underwent tube thoracostomy due to the development of hemothorax/pneumothorax after sharp trauma and $31(77.5 \%)$ of the patients underwent after blunt trauma. In the first group; tube thoraxotomy was performed as a result of pathology due to blunt traumain $13(65.0 \%)$ of the patients and due to sharp trauma in 7 $(35 \%)$ of the patients. In the control group, tube thoraxotomy was performed as a result of pathology due to blunt traumain $18(90.0 \%)$ of the patients and due to sharp trauma in 2 $(10 \%)$ of the patients. There was no significant difference between the groups in terms of trauma type $(p>0.05)$.

Considering the indications for tube thoracostomy; in the first group, $2(10.0 \%)$ of the patients were underwent due to pneumothorax, $6(30.0 \%)$ due to hemothorax and $12(60 \%)$ due to hemopneumothorax. In the control group, $8(40.0 \%)$ of patients were underwent due to pneumothorax, $5(25.0 \%)$ due to hemothorax and 7 (35\%) due to hemopneumothorax. There was no significant difference between the groups in terms of tube thoracostomy indications $(\mathrm{p}>0.05)$.

Among the patients included in this study, 9 $(45.0 \%)$ of the patients in the first group had additional trauma, while $14(70.0 \%)$ of the patients in the control group had additional trauma. There was no significant difference between the groups in terms of additional trauma $(\mathrm{p}>0.05)$.

Tube malposition was present in $14(35 \%)$ of all patients included in our study. $9(45.0 \%)$ of the patients in the first group and $5(25.0 \%)$ of the patients in the control group had tube malposition. There was no significant difference between the groups in terms of tube malposition $(\mathrm{p}>0.05)$.

According to the thoracoscopic findings of the patients who underwent thoracoscopy the following were found: Non-draining hematoma in $10 \quad(50 \%)$ patients; lung parenchymal laceration with non-draining hematoma in $2(10 \%)$ patients; adhesions in 2 (10\%) patients; adhesion and displaced rib fracture in $1(10 \%)$ patient; diaphragm and lung parenchyma laceration in $1(5 \%)$ patient; displaced rib fracture with non-draining hematoma in $1(5 \%)$ patient; adhesion with displaced rib fracture in $1(5 \%)$ patient; active bleeding at the incision site in $1(5 \%)$ patient; and mediastinal hematoma in $1(5 \%)$ patient (Table 1). 
Table 1. Findings of the patients who underwent thoracoscopy

\begin{tabular}{ll}
\hline & N(\%) \\
\hline Non-drained hematom & $10(50)$ \\
\hline Laseration of lung parenchyma with non-drained hematoma & $2(10)$ \\
\hline Cohesions & $2(10)$ \\
\hline Cohesion and displaced rib fractures & $1(5)$ \\
\hline Laserations of diaphragma and lung parenchyma & $1(5)$ \\
\hline Non-drained hematom and displaced rib fractures & $1(5)$ \\
\hline Displaced rib fractures with cohesions & $1(5)$ \\
\hline Active bleeding at stab incision & $1(5)$ \\
\hline Mediastinal hematoma & $1(5)$ \\
\hline
\end{tabular}

The mean tube duration of the patients was $4.7 \pm 1.5$ days in the first group and $6.9 \pm 1.9$ days in the control group. The mean hospitalization time of the patients was $7.1 \pm$ 2.0 days in the first group and $9.3 \pm 3.3$ days in the control group. Hospitalization time and tube insertion time were significantly shorter in patients who underwent thoracoscopy $(\mathrm{p}<$ 0.05) (Table 2).

Table 2. Duration of chest tube staying and duration of hospital stay at the patients to whom thoracoscopy applied and not applied

\begin{tabular}{lccc}
\hline & $\begin{array}{c}\text { VATS (n:20) } \\
\text { AVERAGE +SD }\end{array}$ & $\begin{array}{c}\text { CONTROL(n:20) } \\
\text { AVERAGE +SD }\end{array}$ & P \\
\hline Chest tube duration & $4.7 \pm 1.5$ & $6.9 \pm 1.9$ & $<\mathbf{0 . 0 0 1}$ \\
Hospital stay duration & $7.1 \pm 2.0$ & $9.3 \pm 3.3$ & $\mathbf{0 . 0 1 4}$ \\
\hline
\end{tabular}

Student t-test

The mean WBC value of the patients was 10.7 $\pm 1.510 \mu \mathrm{l}$ in the first group, and $11.6 \pm 3.5$ $\mu 1$ in

the control group. The mean neutrophil percentage of the patients was $75.9 \pm 7.2$ in the first group, and $75.9 \pm 8.4$ in the control group. The mean RDW value of the patients in the first group was $13.5 \pm 1.2$, and $13.6 \pm$ 1.9 in the control group. There was no statistically significant difference between the groups in terms of WBC, neutrophil percentage and RDW (p > 0.05) (Table 3).

Table 3. Comparison of WBC, neutrophile percentage and RW values of the patients to whom thoracoscopy applied and not applied

\begin{tabular}{lccc}
\hline & $\begin{array}{c}\text { CONTS (n:20) } \\
\text { AVERAGE }+ \text { SD }\end{array}$ & P & \\
\hline WBC & $10.7 \pm 3.2$ & $11.6 \pm 3.5$ & 0.391 \\
Neutrophile & $75.9 \pm 7.2$ & $75.9 \pm 8.4$ & 0.970 \\
RDW & $13.5 \pm 1.2$ & $13.6 \pm 1.9$ & 0.880 \\
\hline Student t-test & & &
\end{tabular}

Student t-test 
The mean $\mathrm{pO} 2$ value of the patients was 82.4 $\pm 10.6 \mathrm{mmHg}$ in the first group, and $84.5 \pm$ $15.6 \mathrm{mmHg}$ in the control group. The mean pCO2 value of the patients who underwent VATS was $36.2 \pm 4.5 \mathrm{mmHg}$, and $36.0 \pm 4.5$ $\mathrm{mmHg}$ in the control group. The mean $\mathrm{SO} 2$ value of the patients who underwent VATS was $93.7 \pm 1.7$, and $94.4 \pm 3.0$ in the control group. There was no statistically significant difference between the groups in terms of $\mathrm{pO} 2, \mathrm{pCO} 2$ and $\mathrm{SO} 2$ values $(\mathrm{p}>0.05)$ (Table 4).

Table 4. Comparison of $\mathrm{pO}_{2}, \mathrm{pCO}_{2}$ ve $\mathrm{SO}_{2}$ values at blood gas examination of the patients to whom thoracoscopy applied and not applied

\begin{tabular}{lccc}
\hline & $\begin{array}{c}\text { VATS (n:20) } \\
\text { AVERAGE + SD }\end{array}$ & $\begin{array}{c}\text { CONTROL (n:20) } \\
\text { AVERAGE + SD }\end{array}$ & p \\
\hline $\mathrm{pO}_{2}$ & $82.4 \pm 10.6$ & $84.5 \pm 15.6$ & 0.615 \\
$\mathrm{pCO}_{2}$ & $37.2 \pm 3.3$ & $36.2 \pm 4.5$ & 0.439 \\
$\mathrm{SO}_{2}$ & $93.7 \pm 1.7$ & $94.4 \pm 3.0$ & 0.352 \\
\hline Student t-test & & &
\end{tabular}

patient $(5 \%)$ in the control group was treated with thoracotomy 1 week later due to nondraining hematoma. In the first group, 1 patient $(5 \%)$ was treated with thoracotomy because of the detection of diaphragmatic rupture, which could not be seen in radiological examinations. No statistically significant difference was found between the two groups in terms of thoracotomy requirement $(\mathrm{p}>0.05)$.

\section{Discussion}

Pneumothorax is the accumulation of positive air in the space between the visceral and parietal pleura in the thorax and the development of lung collapse accordingly; it is more common in penetrating traumas than in blunt traumas (14). Hemothorax is the accumulation of blood between the leaves of the pleura and may develop after both penetrating and blunt traumas (15). Thoracic trauma is responsible for approximately $25 \%$ of trauma-related deaths $(16,17)$. While very few of these patients require urgent thoracotomy; treatment, in approximately 85$90 \%$ of the patients, is provided with pain control, tube thoracostomy and respiratory physiotherapy (18). However, some complications that develop in the acute or chronic period, such as coagulum occurring in $18-30 \%$ of patients with traumatic hemothorax and prolonged air leakage in 4$24 \%$ of patients with traumatic pneumothorax, require surgical treatment (19).

Following chest tube administration, chest tube removal is planned after lung expansion on the PA chest radiograph, open monitoring of the costophrenic sinuses, and cessation of air and blood drainage from the chest tube. Failure to withdraw the chest tube due to expansion defect, non-draining hematoma, and prolonged air leakage causes complications such as empyema and fibrothorax (20). Therefore, it is important to with draw the chest tube early without a collection of air or fluid in the pleural space.

If an emergency thoracotomy was not required after tube thoracostomy, hospitalization and monitoring of the patients is the standard treatment. However; despite tube thoracostomy, conditions such as nondraining hematoma and expansion defect require surgical intervention in order to prevent complications such as empyema and fibrothorax. While there were subsidiary treatment methods such as the application of the second and, if necessary, the third tube or exploration with thoracotomy, since the beginning of the 1990s experience accumulated in thoracoscopic interventions and early thoracoscopic interventions have started to be preferred $(21,22)$. It has started to be preferred especially because of its advantages over thoracotomy; such as less pain in the postoperative period, less impact on respiratory functions, reduction in hospital stay and costs $(23,24)$. In our study, it was observed that the duration of removal of chest tubes and the length of hospitalization of the patients in the first group were statistically significantly decreased compared to the control group. 
Thoracoscopy is a very valuable diagnostic method because it provides direct examination. It can be preferred together with laparoscopy for diagnosis, especially in diaphragmatic injuries and radiologically inadequate cases. The diagnostic value of thoracoscopy is between $98-100 \%$ (25). In our study, a diaphragmatic rupture of approximately $2 \mathrm{~cm}$ in width, which could not be detected radiologically, was observed in a patient who underwent thoracoscopy, and the patient was subsequently operated with thoracotomy and diaphragmatic repair was achieved.

Thoracoscopy with sedo-analgesia is a method that has been started to be applied to protect the patient from the risks of general anesthesia, muscle relaxants and intubation, and enable a faster return to daily life. This method has become widespread in recent years, from simple effusion drainages to lobectomies and segmentectomies $(26,27)$. Studies show that thoracoscopy with sedation and regional block is a safe and convenient method. In this group of patients, intrathoracic vagal block or satellite ganglion blockade has been an effective method for cessation of cough reflex. Although long-term results have not been revealed completely yet, it is seen as an alternative to classical thoracoscopy performed with one-lung ventilation under general anesthesia (28). In our study, we applied thoracoscopy to trauma patients with epidural block, stellate ganglion block and sedation, and we saw that it can contribute both in the diagnostic sense and in the primary intervention of simple pathologies.

\section{Conclusion}

As a result, this study showed us that sedoanalgesia and regional blocks may allow us to perform thoracoscopic surgeries and may help us on avoiding side effects of general anesthesia. In addition, we found that thoracoscopy may be a very helpful procedure on treatment of the patients to whom chest tube has been applied because of traumatic haemothoraks or pneumothorax. Besides, it may decrease the complication ratio by shortening the treatment period. And finally we can say that early thoracoscopic surgeries may give us the chance to diagnose soma patologies like diagraphmatic laseration and intrathoracic haemotoma.

\section{REFERENCES}

1. Clark GC, Schecter WP, Trunkey DD. Variables affecting outcome in blunt chest trauma: flail chest vs. pulmonary contusion. J Trauma. 1988 ;28:298304.

2. Cameron P, Dziukas L, Hadj A, et al. Rib fractures in major trauma. Aust $\mathrm{N} Z \mathrm{Z}$ S Surg. 1996;66:530-4.

3. Ahmed Z, Mohyuddin Z. Management of flail chest injury: internal fixation versus endotracheal intubation and ventilation. $J$ Thorac Cardiovasc Surg. 1995;110:1676-80.

4. Yalçınkaya İ, Biliciler U. Traumatic bronchial rupture. Eastern Journal of Medicine. 1999;4:3941

5. Leblebici İ. Kaya Y. Koçak A. Göğüs travmalı 302 olgunun analizi. Türk Göøüs Kalp Damar Cerrahisi Dergisi. Ekim 2005, Cilt 13, Say1 4, Sayfa(lar) 392-396

6. Griffith GL, Todd EP, McMillin RD, et al. Acute traumatic hemothorax. Ann Thorac Surg. 1978 ;26:204-7.

7. Meyer DM, Jessen ME, Wait MA, et al. Early evacuation of traumatic retained hemothoraces using thoracoscopy: a prospective, randomized trial. Ann Thorac Surg. 1997;64:1396-400; discussion 1400-1.

8. Knottenbelt JD, Van der Spuy JW. Traumatic haemothorax--experience of a protocol for rapid turnover in 1,845 cases. S Afr J Surg. 1994 ;32:58.

9. Eddy AC, Luna GK, Copass M. Empyema thoracis in patients undergoing emergent closed tube thoracostomy for thoracic trauma. Am J Surg. 1989;157:494-7.

10. Divisi D, Battaglia C, De Berardis B, et al Videoassisted thoracoscopy in thoracic injury: early or delayed indication? Acta Biomed. 2004;75:158-63.

11. Ikeya T, Sugiyama S, Koyama S, et al. [Traumatic diaphragmatic hernia repaired by video-assisted thoracic surgery; report of two cases]. Kyobu Geka. 2003;56:415-8. Japanese.

12. Cobanoğlu U, Sayir F, Mergan D. İzole travmatik hemotoraksin tedavisinde videotorakoskopik cerrahi ilk tercih olmalı mı? Prospektif randomize kontrolü çalışma [Should videothorascopic surgery be the first choice in isolated traumatic hemothorax? A prospective randomized controlled study]. Ulus Travma Acil Cerrahi Derg. 2011 ;17:117-22. Turkish.

13. Hung $\mathrm{MH}$, Hsu $\mathrm{HH}$, Chan $\mathrm{KC}$, et al. Nonintubated thoracoscopic surgery using internal 
intercostal nerve block, vagal block and targeted sedation. Eur J Cardiothorac Surg. 2014;46:620-5.

14. Cangır AK, Nadir A, Akal M, et al. Göğüs Travmalı 532 olgunun analizi. Ulusal travma dergisi, 2000; 6: 100-5

15. American College of Surgeons Committee on Trauma: Thoracic Trauma. In: Advanced Trauma Life Support for Doctors. Instructor Course Manual. Chicago, III: American College of Surgeons; 1997. p. 147-63

16. Abolhoda A, Livingston DH, Donahoo JS, et al. Diagnostic and therapeutic video assisted thoracic surgery (VATS) following chest trauma. Eur J Cardiothorac Surg. 1997;12:356-60.

17. Manlulu AV, Lee TW, Thung KH, et al. Current indications and results of VATS in the evaluation and management of hemodynamically stable thoracic injuries. Eur J Cardiothorac Surg. 2004 ;25:1048-53.

18. Ahmed N, Jones D. Video-assisted thoracic surgery: state of the art in trauma care. Injury. 2004;35:479-89.

19. Heniford BT, Carrillo EH, Spain DA, et al. The role of thoracoscopy in the management of retained thoracic collections after trauma. Ann Thorac Surg. 1997;63:940-3.

20. Eddy AC, Luna GK, Copass M. Empyema thoracis in patients undergoing emergent closed tube thoracostomy for thoracic trauma. Am J Surg. 1989;157:494-7.

21. Parry GW, Morgan WE, Salama FD. Management of haemothorax. Ann R Coll Surg Engl. 1996 ;78:325-6.

22. Lang-Lazdunski L, Mouroux J, Pons F, et al. Role of videothoracoscopy in chest trauma. Ann Thorac Surg. 1997;63:327-33.

23. Hazelrigg SR, Nunchuck SK, Landreneau RJ, et al. Cost analysis for thoracoscopy: thoracoscopic wedge resection. Ann Thorac Surg. 1993;56:6335 .

24. Landreneau RJ, Hazelrigg SR, Mack MJ, et al. Postoperative pain-related morbidity: videoassisted thoracic surgery versus thoracotomy. Ann Thorac Surg. 1993;56:1285-9.

25. Bosanquet D, Farboud A, Luckraz H. A review of diaphragmatic injury. Respiratory Medicine CME 2 2009; 1-6

26. Katlic MR. Video-assisted thoracic surgery utilizing local anesthesia and sedation. Eur $J$ Cardiothorac Surg. 2006;30:529-32.

27. Mineo TC. Epidural anesthesia in awake thoracic surgery. Eur J Cardiothorac Surg. 2007;32:13-9.

28. Chen $\mathrm{KC}$, Cheng $\mathrm{YJ}$, Hung $\mathrm{MH}$, et al. Nonintubated thoracoscopic surgery using regional anesthesia and vagal block and targeted sedation. J Thorac Dis. 2014;6:31-6. 